\title{
Assessing food sustainable intensification potential of agroforestry using a carbon balance method
}

\author{
Josep Crous-Duran ${ }^{(1)}$, \\ Anil R Graves ${ }^{(2)}$, \\ Silvestre Garcia-de-Jalón ${ }^{(2-3)}$, \\ Joana A Paulo (1), \\ Margarida Tomé (1), \\ João HN Palma ${ }^{(1)}$
}

Food security, climate change mitigation, and land use challenges are interlinked and need to be considered simultaneously. One possible solution is sustainable intensification, which is the practice of increasing food production per area of land whilst also reducing the environmental impacts associated with this. Agroforestry has been stated to be a practice that meets this definition. In this study, a new methodology is presented to assess the potential of different management options as sustainable intensification practices. The methodology is based on comparing the carbon emissions associated with the production of food and the carbon sequestered for that same activity for a particular quantity of food produced over a specific area and over a specific time. The resulting indicator, the "carbon balance" is the difference between the greenhouse gasses emitted (considered as negative values) and carbon sequestered (positive values) estimated in $\mathrm{Mg} \mathrm{CO}_{2 \text { eq }}$ per $\mathrm{Mg}$ of food produced on one hectare of land for one year. The carbon balance quantifies the global warming potential associated with sustainable intensification by integrating a process-based model with life cycle analysis and is able to estimate above- and below-ground biomass and soil carbon content. This methodology is tested in Portugal for wheat production under crop monoculture and agroforestry systems. The results show agroforestry to be a suitable practice for sustainable intensification compared to a crop monoculture as it just slightly decreased wheat yields whilst providing a positive carbon balance from year $\mathbf{5 0}$ onwards of approximately $1 \mathrm{Mg}$ of $\mathrm{CO}_{2 \text { eq }}$ sequestered per $\mathrm{Mg}$ of wheat produced.

Keywords: Climate Change Mitigation, Food Security, Land-use Occupation, Regulating Ecosystem Services, Soil Fertility, Life Cycle Analysis, Yield-SAFE, Clipick, Carbon Sequestration

United Nations (FAO 2009) stated that the challenges associated with the reduction of GHG emissions, food security, and land use should be dealt with simultaneously on the same land parcel. Since then, even though the concept is unclear even for experts (Petersen \& Snapp 2015), sustainable intensification ( $\mathrm{SI}$ ) has been identified as a strategy for improving food security while maintaining biodiversity and ecosystems services (Godfray et al. 2012, Godfray \&
(1) Forest Research Centre, School of Agriculture, University of Lisbon, Tapada da Ajuda s/n, 1349-017 Lisbon (Portugal); (2) Cranfield University, Cranfield, Bedfordshire, MK43 OAL (UK); (3) Basque Centre for Climate Change (BC3), 48940, Leioa, Basque Country (Spain)

@ Josep Crous-Duran (jcrous@isa.ulisboa.pt)

Received: Aug 01, 2017 - Accepted: Nov 10, 2018

Citation: Crous-Duran J, Graves AR, Garcia-de-Jalón S, Paulo JA, Tomé M, Palma JHN (2019). Assessing food sustainable intensification potential of agroforestry using a carbon balance method. iForest 12: 85-91. - doi: 10.3832/ifor2578-011 [online 2019-01-24]

Communicated by: Piermaria Corona

\section{Garnett 2014)}

Agroforestry is one of the most common land use practice worldwide (Den Herder et al. 2017). It consists of integrating woody vegetation with crop and/or animal production and it has been often referred to as an example of a SI practice that is able to satisfy food security concerns while producing other benefits (Glover et al. 2012, Godfray et al. 2012). It can provide higher yields of provisioning ecosystem services (food, materials, and energy) in comparison with obtaining the same provisioning ecosystem services from monoculture systems (Graves et al. 2010, Torralba et al. 2016, Crous-Duran et al. 2018). At the same time agroforestry can reduce soil erosion, nitrate leaching (Palma et al. 2007), greenhouse gas emissions and potentially achieve net carbon sequestration per unit of product (Godfray et al. 2012, Vermeulen et al. 2012). In Portugal, agroforestry systems are extensively found in the form of the montado, which combines low density (less than 80 trees per hectare) spatially dispersed cork oak trees (Quercus suber) and holm oak trees (Quercus ilex subsp. ro- 
tundifolia) with pasture on which livestock graze freely. The montado occupies around 0.75 million ha in Portugal and its equivalent system in Spain (dehesas) around 1.5 million ha. The most important product provided by the montado is cork, and Portugal is the world's largest cork producer with $49.6 \%$ of world cork production. The system provides other provisioning ecosystem services such as wood, charcoal, crops, fodder, meat, dairy products, honey, mushrooms, and medicinal and aromatic plants (Pereira \& Fonseca 2003, Pinto-Correia et al. 2011, Moreno et al. 2017). In the 1930s, in order to increase internal food production, cereal cultivation under the trees was promoted, and a silvoarable version of the montado developed. However, this intensification process (including mechanisation and fertilisation) occurred without considering the fragility and low quality of the soils. As a consequence, tree density was reduced, the roots of the remaining trees were affected and the soil erosion increased. All together lead to a general impoverishment of the soils and a further decrease in crop yields which in the following years caused the final abandonment of the fields (Pinto-Correia 1993).

Physiological growth models are models that simulate ecological processes in order to estimate vegetative growth. These models are useful in decision-making that relates to the management of natural resources in the context of climate change (Cuddington et al. 2013). The agroforestry model Yield-SAFE is a process-based model that simulates competition between trees and crops for water and light. It has been widely used in Europe including for silvo- arable systems of poplar and cereals in the UK, Netherlands, Spain, and France (Graves et al. 2010); cherry tree pastures in Switzerland (Sereke et al. 2015) and the Portuguese montado (Palma et al. 2014). Recently, during the AGFORWARD project (Burgess \& Rosati 2018) the model was further developed and calibrated for more tree and crop species (Palma et al. 2016, 2017b).

In this study we have developed a so called "carbon balance method" which quantifies GHG emissions using Life Cycle Assessment (LCA) for estimating the Global Warming Potential (GWP) of crop and tree production as well as the positive effects of carbon sequestration. Applied to crop production, this approach could be useful for estimating the SI potential of different land management practices. The method follows FAO which advocates reducing GHG emissions advice (for climate change mitigation), increasing food production (for food security), and reducing land occupation (for reduced land use change) simultaneously by comparing the level of greenhouse gas emitted by the practice (using the GWP impact from a LCA approach) with the carbon sequestered by the system (using a process-based growth model) for the same yield of product (Mg of food) per area of land (hectare). The carbon balance of the product (in $\mathrm{CO}_{2 \text { eq }}$ per $\mathrm{Mg}$ of food) provides a means of comparing the impact of food production under different management practices. The methodology is tested by comparing the carbon balance for growing $1 \mathrm{Mg}$ of wheat in central Portugal using two alternative management scenarios: (i) a wheat crop monoculture; and (ii) a montado agrofor- estry system combining wheat cultivation with low density cork oak trees (Quercus suber L.).

\section{Materials and methods}

\section{Definition of management scenario options}

For this study, two different management options for wheat cultivation were compared: (i) wheat monoculture crop system; and (ii) montado agroforestry system combining wheat production with cork oak. Growth of both land use alternatives were simulated using the improved version of the Yield-SAFE model (Palma et al. 2016, 2017b). Both management options were simulated for Montemor-o-Novo (Portugal - longitude: $38.72^{\circ}$; latitude: $-8.32^{\circ}$ ). In this region, the most common wheat specie produced is Triticum aestivum L. Average yields from 1990 to 2011 in Portugal were around $1.4 \mathrm{Mg} \mathrm{ha}^{-1}$ year $^{-1}$ (Almeida \& Maças 2016). In Portugal, wheat is sown in the autumn (November) when temperatures begin to fall. Vegetative growth takes place in winter and it is harvested in early summer in the first weeks of June, before the hottest months of the year (Rosado 2009). For this study, the rotation simulated was a typical wheat-wheat-fallow rotation.

Whilst the crop monoculture land use was assumed to be planted on $100 \%$ of each hectare, the agroforestry management option assumed a crop area that covered $90 \%$ with $10 \%$ of each hectare being covered by trees. These were assumed to be planted at an initial density of 200 trees $\mathrm{ha}^{-1}$, and then thinned every 10 years to reach a final density of 35 trees $^{-1} a^{-1}$ at year 70.

\section{Global warming potential}

The carbon balance method for this study used the conversion factors published by the IPCC (Intergovernmental Panel on Climate Change - IPCC 2006) and considered the GWP of different gaseous emissions through a common metric $\left(\mathrm{CO}_{2 \mathrm{eq}}\right)$ which in this study expresses the potential contribution of gaseous emissions to global warming over a time horizon of 100 years (GWP 100).

Sources of gaseous emissions were associated with the management practices for wheat and cork oak (Kramer et al. 1999, Gonzalez-Garcia et al. 2013) including the operations for the establishment of the stand, maintenance and growth, harvesting, and the transport of system products and workforce. In agroforestry, the emissions from the cork oak stand management and wheat were considered proportionally to the area occupied by the tree and the crop components for field operations (10\% and 90\%, respectively) but the same distance was used for the transport of system products and the workforce ( 5 $\mathrm{km})$.

The three main GHG gases included in the study were carbon dioxide $\left(\mathrm{CO}_{2}\right)$, methane 
$\left(\mathrm{CH}_{4}\right)$ and nitrous oxide $\left(\mathrm{N}_{2} \mathrm{O}\right)$. These were assessed for four main sources including: (i) the combustion of fuels used in the field operations; (ii) the emissions related to the production and application of fertilisers and seeds; (iii) the transport of the products from field to farm; and (iv) soil microbial activity.

For the wheat systems, field operations included ploughing with disk harrows at the beginning of November and harrowing at the same time as sowing two weeks later. For sowing, a fine grain seeder was used at a seeding rate of $180 \mathrm{~kg} \mathrm{ha} \mathrm{H}^{-1}$ and $\mathrm{Di}$ ammonium phosphate (18:46:0) applied at a rate of $250 \mathrm{~kg} \mathrm{ha}^{-1}$. In March, fertiliser was applied again using $170 \mathrm{~kg} \mathrm{ha}^{-1}$ of ureabased fertiliser $(46 \% \mathrm{~N})$. Weeding was accomplished by using a single application of $0.4 \mathrm{~kg} \mathrm{ha}^{-1}$ of herbicide 2,4-D. A combined harvester was used for harvesting the wheat (Tab. 1).

In the cork oak agroforestry systems, the time required for field operations and the rate of fuel consumption for field operations was established using national data (CAOF 2010). Field operations included soil preparation to clear vegetation, and the ripping and ploughing of all the area. It was assumed that the ploughing for the wheat and for the trees would be done at the same time. The trees were assumed to require fertilization at the rate of $125 \mathrm{~g}$ of NPK (7:21:21) per plant (Gonzalez-Garcia et al. 2013). During the first year, $20 \%$ of the trees were assumed to require replacement due to mortality without additional fertilizer being applied. Pruning was assumed to be required every eight years and cork debarking every nine years, but this was done manually and therefore not considered to be a GHG emission source. Usually in a cork oak plantation, vegetation clearing is undertaken every four to five years, but as wheat is cultivated in the area between the trees, this operation was not included here. A petrol chainsaw was considered for pruning and thinning operations (Tab. 2).

Kramer et al. (1999) reported 0.241, 2.66 and $3.96 \mathrm{~kg} \mathrm{CO}_{2 e q} \mathrm{~kg}^{-1}$ for the production of wheat seeds, nitrogen fertiliser, and pesticides respectively. GHG emissions derived from the use of nitrogen fertiliser were added to the field operation emissions, since approximately $2.55 \%$ of $\mathrm{N}$-fertiliser is converted to $\mathrm{N}_{2} \mathrm{O}$ (Rajaniemi et al. 2011).

\section{Modelling with Yield-SAFE}

The Yield-SAFE model is a process-based dynamic model for predicting resource capture, growth, and production in forestry, agroforestry and agricultural systems (Van Der Werf et al. 2007, Palma et al. 2016, 2017b). The model can be used to estimate carbon sequestered by the tree and crop biomass and the soil using an application of the RothC model within Yield-SAFE (Palma et al. 2017a). The carbon sequestered was estimated assuming that $50 \%$ of the biomass was carbon. Biomass in this

Tab. 2 - Source of greenhouse gas emissions for cork oak agroforestry management. (a): Gonzalez-Garcia et al. (2013); (b): Kramer et al. (1999); (c): IDAE (2005); (d): Mäkelä (2002); (e): CAOF (2010); (g): IPCC (2006); (h): based on the conversion factor for $\mathrm{N}$ fertiliser to $\mathrm{N}_{2} \mathrm{O}$ emissions of $2.55 \%$ (Rajaniemi et al. 2011); $\left({ }^{*}\right)$ : the values for pruning and thinning operation are presented per tree as the total value depend on the tree density.

\begin{tabular}{|c|c|c|c|}
\hline Input production & Quantity & $\begin{array}{c}\text { GWP } 100 \\
\left(\mathrm{~kg} \mathrm{CO}_{2} \text { eq kg }{ }^{-1}\right)\end{array}$ & $\begin{array}{c}\mathrm{GHG} \\
\left(\mathrm{kg} \mathrm{CO}{ }_{2} \text { eq) }\right.\end{array}$ \\
\hline Plants (trees ha-1) & 200 & - & - \\
\hline Fertiliser $\left(\mathrm{kg} \mathrm{N} \mathrm{ha}^{-1}\right)$ & 1.75 & $2.66^{\mathrm{b}}$ & 4.6 \\
\hline Sub total & & & 4.6 \\
\hline Field operations & $\begin{array}{l}\text { Consumption } \\
\left(\mathrm{I} \mathrm{ha}^{-1}\right)\end{array}$ & $\begin{array}{c}\text { GWP } 100 \\
\left(\mathrm{~kg} \mathrm{CO}_{2} \text { eq l}^{-1}\right)\end{array}$ & $\begin{array}{l}\text { GHG emissions } \\
\left(\mathrm{kg} \mathrm{CO}_{2} \mathrm{eq}\right)\end{array}$ \\
\hline Clearing & $6.8^{c}$ & $2.6^{\mathrm{d}}$ & 17.7 \\
\hline Ripping & $20.0^{c}$ & $2.6^{d}$ & 52.0 \\
\hline Plough with disc harrows & $9.8^{c}$ & $2.6^{\mathrm{d}}$ & 25.48 \\
\hline Planting+Fertilization & Manual & - & - \\
\hline Replanting & Manual & - & - \\
\hline Transport of workers (5 km) & $1.5^{c}$ & $2.6^{d}$ & 3.9 \\
\hline Sub Total & - & - & 99.08 \\
\hline Tree operations & $\begin{array}{l}\text { Consumption } \\
\left(\text { ( tree }{ }^{-1}\right)\end{array}$ & $\begin{array}{c}\text { GWP } 100 \\
\left(\mathrm{~kg} \mathrm{CO}_{2} \text { eq l}^{-1}\right)\end{array}$ & $\begin{array}{l}\text { GHG emissions } \\
\left(\mathrm{kg} \mathrm{CO}_{2} \mathrm{eq}\right)\end{array}$ \\
\hline Pruning (depends on tree density) & $0.26^{\mathrm{e}}$ & $2.3^{\mathrm{d}}$ & $0.6^{*}$ \\
\hline Thinning (depends on tree density) & $0.10^{\mathrm{e}}$ & $2.3^{d}$ & 0.2 * \\
\hline Debarking & Manual & - & - \\
\hline Sub Total & - & - & 0.8 \\
\hline Emission from fertilisers & $\begin{array}{l}\mathrm{N}_{2} \mathrm{O} \text { emissions } \\
\left(\mathrm{kg} \mathrm{N}_{2} \mathrm{O}\right)\end{array}$ & $\begin{array}{c}\text { GWP } 100 \\
\left(\mathrm{~kg} \mathrm{CO}_{2} \text { eq N2 } \mathrm{N}^{-1}\right)\end{array}$ & $\begin{array}{l}\text { GHG emissions } \\
\left(\mathrm{kg} \mathrm{CO} \mathrm{CO}_{2} \mathrm{eq}\right)\end{array}$ \\
\hline Emissions from $\mathrm{N}$ fertiliser (1.75 kg N) & $0.04^{\mathrm{h}}$ & $298^{\mathrm{g}}$ & 13.29 \\
\hline Sub Total & - & - & 13.29 \\
\hline Total & - & - & 117.77 \\
\hline
\end{tabular}

study included above-ground biomass (AGB) and below-ground biomass (BGB) that is estimated using a root-to-shoot ratio of 0.43 and 0.31 for cork oak and wheat, respectively (Palma et al. 2014, Siddique et al. 1990), but excluded output products of both systems, including wood from pruning, cork debarked, wheat grain and straw. Tree leaves and roots and wheat roots after harvesting were included as inputs for the soil carbon model. The period of simulation was 80 years and the weather data used for the simulations was extracted from Clipick (Palma 2017) which uses data from the KNMI regional atmospheric climate model RACMO ver. 2.2 previously tested in the country (Palma et al. 2018). Cork oak and wheat parameter sets for Yield-SAFE were taken from Palma et al. (2014, 2017b).

\section{Carbon balance estimation}

The estimation of the Carbon Balance of the wheat and agroforestry systems was calculated as the difference between: (1) the amount of GHG emissions with GWP $\left(\mathrm{CO}_{2 e q}\right)$ emitted by different activities and products used during the growth process; and (2) the amount of carbon sequestered in the above- and below-ground biomass and in the soil (Fig. 1). The $\mathrm{CO}_{2 e q}$ emissions released from soil biota were included as GHG emission (soil respiration). Results were expressed in $\mathrm{Mg}$ of $\mathrm{CO}_{2 \text { eq }} \mathrm{Mg}$ of wheat grain ${ }^{-1}$.

\section{Results}

\section{Predicted yields of the Yield-SAFE} model

The average wheat yield over 80 years for the wheat monoculture was predicted by Yield-SAFE to be $1.73 \mathrm{Mg}^{-1}$ hear $^{-1}$ (excluding the fallow years - Fig. 2). This yield was slightly higher than the expected wheat yield in the country that is of $1.4 \mathrm{Mg} \mathrm{ha}^{-1}$ year ${ }^{-1}$ (Almeida \& Maças 2016). The agroforestry wheat on a per hectare crop basis, compared to the monoculture wheat, had similar yields during the first part of the simulation period (from year 1 to year 30), slightly lower yields during the middle part of the simulation period (from year 30 to year 50), and much lower yields during the last part of the simulation period (from year 50 to year $80-$ Fig. 2). However, on average, wheat production on the agroforestry system was of $1.53 \mathrm{Mg} \mathrm{ha}^{-1}$ year ${ }^{-1}$. The accumulated biomass in the tree component was approximately $0.650 \mathrm{Mg}$ tree $^{-1}$ and this was similar to the above-ground biomass for trees of the same age in similar conditions in Portugal (Palma et al. 2014).

\section{Carbon balance}

The predicted GWP for wheat of $0.81 \mathrm{Mg}$ $\mathrm{CO}_{2 \mathrm{eq}} \mathrm{Mg}$ of wheat ${ }^{-1}$ was close to that reported by Rosado (2009) for lower average yields, i.e., $1.08 \mathrm{MgCO}_{2 \mathrm{eq}} \mathrm{Mg}$ of wheat ${ }^{-1}$. For cork oak, Gonzalez-Garcia et al. (2013) reported a GWP potential from forest opera- 


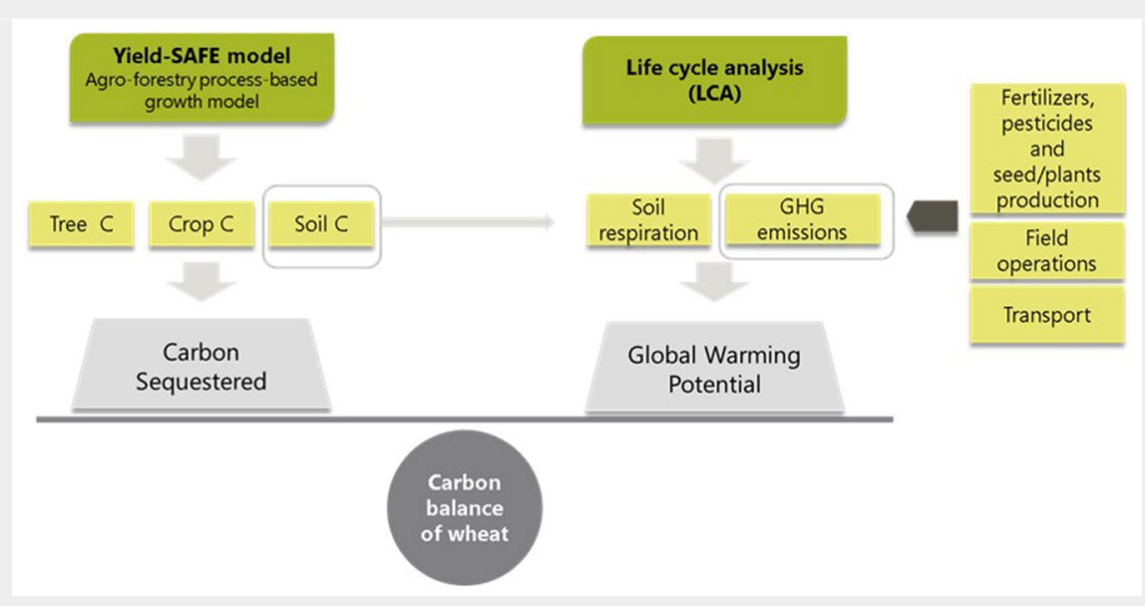

Fig. 1 - Methodology used to estimate the carbon balance of a functional unit ( $\mathrm{Mg}$ of $\mathrm{CO}_{2 \text { eq }} \mathrm{Mg}$ of wheat grain ${ }^{-1}$ ) by comparing the estimation of the Yield-SAFE model of the carbon sequestered by the tree, crop and soil components and the greenhouse gas emissions derived from fertilizers, pesticides and seed/plants production, field operations, transport and soil respiration.

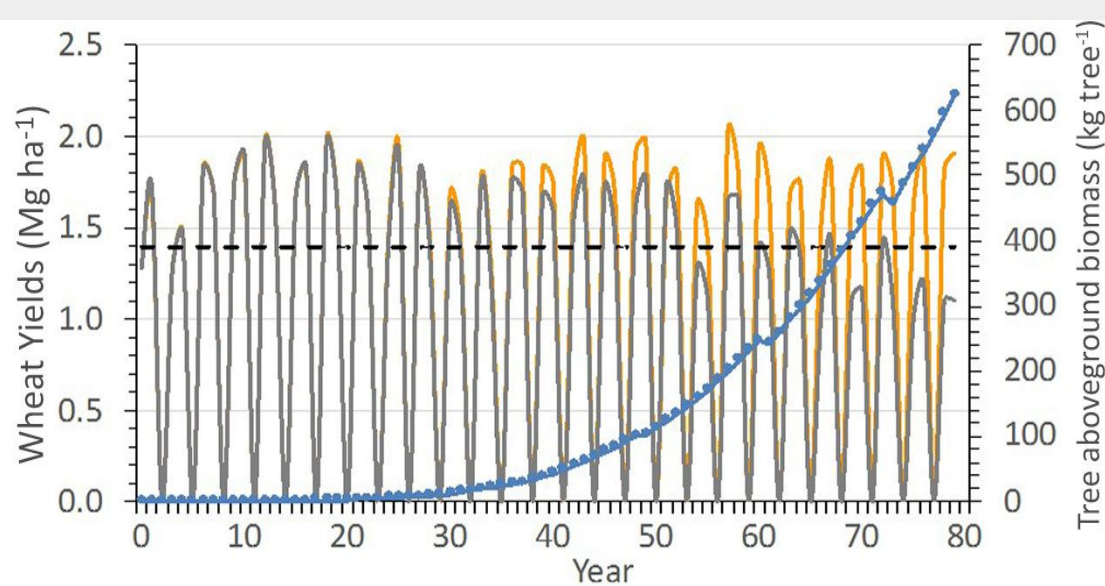

Wheat yield in Monoculture - - Observed average wheat yield in Portugal Wheat yield in Agroforestry —Tree biomass in Agroforestry

Fig. 2 - Tree growth and wheat yields simulated by the Yield-SAFE model for a wheat monoculture (wheat yield in monoculture) and an agroforestry system (wheat yield in agroforestry and tree biomass in agroforestry) combining wheat and cork oak trees in Portugal, compared to the observed average yield in Portugal for the period 1990-2011 by Almeida \& Maças (2016 - observed average wheat yield in Portugal). tion of $1.64 \mathrm{Mg} \mathrm{CO}_{2 e q}$ ha $^{-1}$ for a cork oak stand of 100 tree ha ${ }^{-1}$, whilst in this study, the GWP from forest operations (including fertiliser use) were $0.49 \mathrm{Mg} \mathrm{CO}_{2 \mathrm{eq}} \mathrm{ha}^{-1}$, although this was for a final tree density of 35 tree ha ${ }^{-1}$ and did not include the vegetation clearing operation that occurred every 3-4 years in Gonzalez-Garcia et al. (2013). In terms of carbon sequestration of the tree component of the system, the aboveground biomass estimated in this study was $1.19 \mathrm{Mg} \mathrm{CO}_{2 \mathrm{eq}}$ in year $80(0.325 \mathrm{Mg} \mathrm{C}$ tree $\left.^{-1}\right)$. This is similar to Palma et al. (2014) who used Yield-SAFE and the same carbon sequestration method for a slightly higher final tree density (50 trees ha ${ }^{-1}$ ) agroforestry system in Portugal and reported a cork oak tree carbon content of $1.32 \mathrm{Mg}$

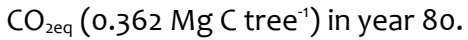

GHG emissions from wheat field operations, and fertiliser, seed and pesticide production were the main contributions to the GWP identified (GHG emissions in Fig. 3). For agroforestry were quantified in the range of $\mathrm{o}$ and $1.34 \mathrm{MgCO}_{2 \mathrm{eq}}$ ha $^{-1}$ depending on crop and tree field operations (GHG emissions in Fig. 3) and of between 0 and $1.4 \mathrm{Mg} \mathrm{CO}_{2 \mathrm{eq}} \mathrm{ha}^{-1}$ for the monoculture system, depending if wheat was cultivated or not. This source of emission was slightly lower for agroforestry due to the fact that crop area was also lower (10\% less). Respiration from the soil biota activity was also a source of GHG emissions (soil respiration in Fig. 3) and was related to the crop yield: the soil can act as a sink or as an emitter of carbon, depending on the quantity of plant material accumulated in the soil during the year. In the wheat monoculture system, even in wheat cultivation years, the input of plant material was not sufficient to offset soil carbon loss by respiration, and soil carbon content decreased by $20 \%$ over the simulation period. By contrast, in the agroforestry system, additional input from trees (roots and leaves) allowed the soil to increase the quantity of carbon stored and therefore act as a carbon sink, and this especially from year 35 onwards (Fig. 3 ). The effects of the gains or losses in terms of

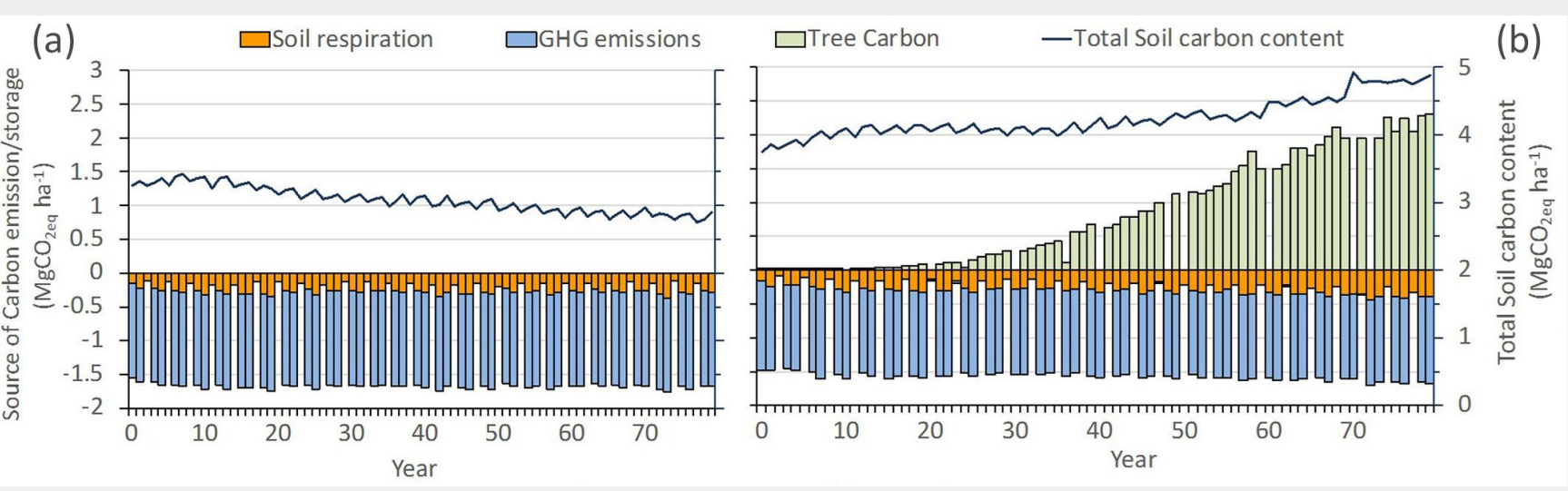

Fig. 3 - Carbon sources of emissions and storage (in $\mathrm{MgCO}_{2}$ ha $^{-1}$ ) for monoculture (a) and agroforestry (b) management systems for wheat production including emissions from soil biota respiration (soil respiration), from field operations and fertiliser, seed and pesticide production (GHG emissions) and carbon sequestered by tree (tree carbon) and stored in soil (total soil carbon content). 


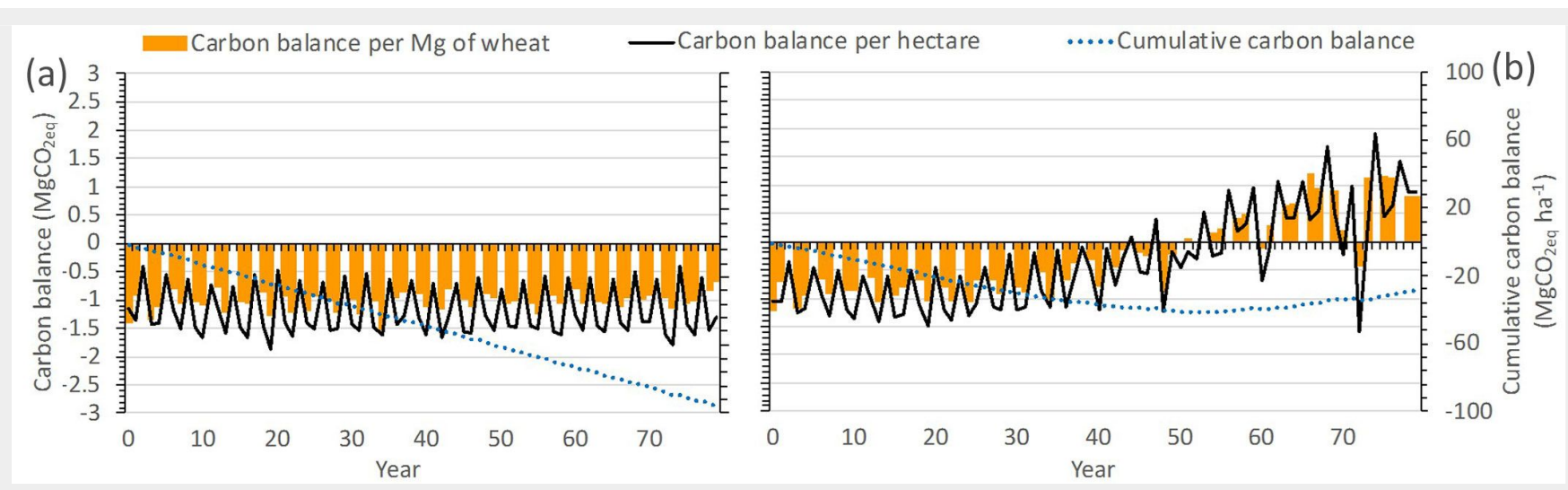

Fig. 4 - Differences between carbon emissions and carbon sequestered per ton of wheat produced (carbon balance per Mg of wheat), per hectare of system occupied by (a) monoculture or (b) agroforestry (carbon balance per hectare) and the cumulative values (cumulative carbon balance) for two management option for wheat production in Portugal (monoculture and agroforestry).

carbon in soil are reflected in the total soil carbon content (Fig. 3). The tree component (tree carbon in Fig. 3) of the agroforestry system was the largest carbon sink for most of the simulation period. During the thinning years the amount of carbon stored in the tree component was assumed to be neutral, i.e., there are neither losses nor gains of carbon in the tree component. This is because in thinning years the tree density is reduced and the remaining trees do not compensate the carbon losses derived. As these outgoing trees continue to store the carbon even outside the system, it is considered that during these years there is neither positive nor negative tree growth.

\section{Agroforestry for food sustainable intensification}

The second step of this study was to assess the balance between the GHG emitted and the carbon sequestered during production of wheat in the agroforestry and monoculture systems. If the same quantity of wheat is produced on the same area of land, with reduced carbon emissions, this can be considered to satisfy the SI process. The average yield in the agroforestry system (1.53 Mg of wheat ha ${ }^{-1}$ year ${ }^{-1}$ ) was found to be slightly lower over the 80 year simulation period than the monoculture yield (1.73 Mg of wheat ha ${ }^{-1}$ year $\left.{ }^{-1}\right)$. Results showed that in the monoculture management option, the production of $1 \mathrm{Mg}$ of wheat was associated with a negative carbon balance result of $1 \mathrm{Mg} \mathrm{CO}$ eq (Fig. 4). In agroforestry, the production of $1 \mathrm{Mg}$ of wheat was linked to an initial negative carbon balance of around $1 \mathrm{Mg} \mathrm{CO}_{2 \text { eq }}$ whilst the trees were small. But as the trees grew over time, the carbon balance improved and by year 50 became positive, suggesting that agroforestry, when the trees become mature, could have a positive carbon balance of $1 \mathrm{Mg} \mathrm{CO}_{2 \text { eq }}$ for the production of each Mg of wheat (Fig. 4).

\section{Discussion}

The methodology presented here inte- grates process-based modelling and LCA so that changes in practices that could lead to sustainable intensification can be evaluated. This is done by comparing the GHG emissions and carbon sequestration tradeoff of a functional unit, in this study, the production of $1 \mathrm{Mg}$ of wheat. Furthermore, the carbon balance integrates dimensions that can be used to consider the three main challenges for $\mathrm{SI}$ referred to by the FAO, which include: (i) food security; (ii) climate change mitigation; and (iii) land occupation. Producing results in terms of a carbon balance per $\mathrm{Mg}^{-1}$ crop ha-1 year ${ }^{-1}$ helps to provide an approach that can be used to make the SI concept more workable, an aspect of the concept that has been challenging (Petersen \& Snapp 2015).

In this study, the results of the carbon balance for wheat under two different land management options has confirmed that the agroforestry option provided an improvement over the monoculture because it: (i) produced similar yields (ensures food security); (ii) helped with climate change mitigation (positive carbon balance after year 50); and (iii) avoided the need to increase the area of land occupied by agriculture as per hectare yields were similar to the monoculture option.

In agroforestry systems the integration of woody vegetation together with wheat allows the system to make a more efficient use of natural resources such as light and water, resulting in higher land equivalent ratios that can be achieved by growing trees and crops separately (Graves et al. 2010). This may be due to complementarity in the use of resources or sometimes because trees may help to retain natural resources such as soil and water, increasing the amount of energy accumulated and the provisioning of ecosystem services (CrousDuran et al. 2018). However these findings are also contested (Cubera et al. 2009, Rivest et al. 2011, Torralba et al. 2016). Nevertheless, the algorithms recently implemented in Yield-SAFE (Palma et al. 2016) attempt to account for the effect that trees have on buffering minimum and maximum temperatures whilst reducing wind speeds. This leads to reduced water losses due to reduced evapotranspiration, enabling an extension of the growing season, or at least as in this study, maintain yields despite tree competition.

The agroforestry system here was found to reduce GHG emissions directly. In fact, even if the combination of the two activities (forestry and agriculture) increased the number of field operations required, the reduction of area dedicated to crop and the fertiliser used reduced the total GHG emitted for the crop area from $1.4 \mathrm{Mg}$ $\mathrm{CO}_{2 \mathrm{eq}}$ to $1.27 \mathrm{Mg} \mathrm{CO}_{2 \mathrm{eq}} \mathrm{ha}^{-1}$. However, here, after year 50 of the rotation, a positive carbon balance was nevertheless achieved and this was due to the incorporation of the trees that after a certain amount of time were able to numerically offset the GHG emissions associated with both activities whilst maintaining a similar level of crop production.

The increase in the demand for food has been met either by increasing fertiliser, machinery use, or genetic improvement (intensification), or by increasing the area of land occupied by agriculture (extensification). Both strategies have large impacts on GHG emissions and if badly managed can lead to an impoverishment of soils and in a reduction of yields as a consequence, as was the case in the silvoarable montado in Portugal (Pinto-Correia 1993). Agroforestry is a strategy that can help to increase food production without requiring the conversion of new land. As noted by the FAO, this is an important aspect of intensification.

Furthermore, agroforestry helps provide important environmental benefits like reducing soil erosion (Nair 2007), nitrate leaching (Palma et al. 2007, Jose 2009), net greenhouse gas emissions (Godfray et al. 2012) and improve biodiversity conservation (Torralba et al. 2016), soil enrichment (Graves et al. 2015) and enhance climate change mitigation by sequestering more carbon in soils (Cardinael et al. 2017). Whilst, not evaluated in this study, these 
benefits strengthen the case for the promotion and implementation of agroforestry systems in Europe as SI practices.

Compared to crop monocultures of trees and crops, agroforestry systems can help to ensure farm profitability as crop yields and tree growth are similar or even higher (García De Jalón et al. 2018), enhance financial security as production is diversified and stimulate rural economics through new product streams.

In the case of Portugal, this work suggests that implementation of agroforestry systems instead of crop monocultures for wheat production is preferable, because this land use option, when mature (from year 50 onwards), could provide a net carbon sequestration rate of around one $\mathrm{Mg}$ of $\mathrm{CO}_{2 \text { eq }}$ for every $\mathrm{Mg}$ of wheat produced; and even more when considering that in the existent soil and climate conditions other agricultural uses would be of difficult implementation (Pinto-Correia 1993). In Portugal in 2011, the area of wheat production was 276,000 ha and the average wheat yield was about $1.4 \mathrm{Mg} \mathrm{ha}^{-1}$ producing a total of $386,400 \mathrm{Mg}$ of wheat per year (Almeida \& Maças 2016). A change of production from crop monoculture to agroforestry could result in substantial carbon sequestration in the near future to offset the GHG emissions associated with wheat production.

The carbon balance method presented here appears to be a useful approach for evaluating SI practices. In this study, the method was applied to wheat production in Portugal as this is a significant crop in the country and globally. However, the carbon balance method could be used for evaluating other provisioning ecosystem services, including other crops, meat, timber, cork, nuts or fruit. The method could also be applied to forestry and orchard systems as the base methodologies used (LCA approach and Yield-SAFE model) are compatible.

\section{Conclusion}

This study compares the carbon emissions and carbon sequestration to produce a carbon balance of the product being assessed. Applied to food production the method here enables the SI of different management options to be compared. The results in $\mathrm{Mg} \mathrm{CO}_{2 \text { eq }} \mathrm{Mg}_{\text {food }}^{-1}$ applied for the same area ( 1 ha of system) and time (1 year) facilitate this comparison. Positive values represent net carbon sequestration whilst negative values represent net carbon emissions. The SI potential was analyzed for wheat production for two different management options, a crop monoculture and an agroforestry system. The crop monoculture had a negative carbon balance during the entire simulation (80 years) of around $1 \mathrm{Mg} \mathrm{CO}_{2 \text { eq }} \mathrm{Mg}$ wheat. Under a cork oak agroforestry system, the carbon balance was positive from year 50 onwards and for every $\mathrm{Mg}$ of wheat produced $1 \mathrm{Mg}$ of carbon dioxide equivalent was sequestered, confirming that agroforestry could be used as a SI practice.

\section{Acknowledgments}

We acknowledge the financial support provided by the Portuguese Foundation for Science and Technology (FCT) through the scholarship SFRH/BD/52691/2014 and PEST (UID/AGR/00239/2013) and the European Community's Seventh Framework Programme under Grant Agreement No. 613520 (Project AGFORWARD).

\section{References}

Abrahão R, Carvalho M, Causapé J (2017). Carbon and water footprints of irrigated corn and non-irrigated wheat in Northeast Spain. Environmental Science and Pollution Research 24: 5647-5653. - doi: 10.1007/s11356-016-8322-59

Almeida A, Maças B (2016). The history of wheat breeding in Portugal. In: "The World Wheat Book: A History of Wheat Breeding" (Bonjean AP, Angus W, Van Ginkel M eds). Lavoisier publishing, Paris, France, vol. 3, pp. 93-125.

Burgess PJ, Rosati A (2018). Advances in European agroforestry: results from the AGFORWARD project. Agroforestry Systems 92 (4): 801-810. - doi: 10.1007/s10457-018-0261-3

CAOF (2010). CAOF - Comissão de Acompanhamento para as Operações Florestais [Monitoring Commission for Forest Operations]. Direção General de Agricultura e Desenvolvimento Rural, Lisbon, Portugal. Website. [in Portuguese] [online] URL: http://www.dgadr.pt/18mecanizacao-agraria/127-caof

Cardinael R, Chevallier T, Cambou A, Béral C, Barthès BG, Dupraz C, Durand C, Kouakoua E, Chenu C (2017). Increased soil organic carbon stocks under agroforestry: a survey of six different sites in France. Agriculture, Ecosystems and Environment 236: 243-255. - doi: 10.1016/j. agee.2016.12.011

Crous-Duran J, Graves A, Paulo JA, Mirck J, Oliveira TS, Kay S, Palma JHN (2018). Modelling tree density effects on provisioning ecosystem services in Europe. Agroforestry Systems. [in press] - doi: 10.1007/s10457-018-0297-4

Cubera E, Nunes JM, Madeira M, Gazarini L (2009). Influence of Quercus ilex trees on herbaceous production and nutrient concentrations in southern Portugal. Journal of Plant Nutrition and Soil Science 172: 565-571. - doi: 10.1002/ jpln.200800191

Cuddington $\mathrm{K}$, Fortin $\mathrm{M}-\mathrm{J}$, Gerber LR, Hastings A, Liebhold A, O'Connor M, Ray C (2013). Processbased models are required to manage ecological systems in a changing world. Ecosphere 4: art2O. - doi: 10.1890/ES12-00178.1

Den Herder M, Moreno G, Mosquera-Losada RM, Palma JH, Sidiropoulou A, Santiago Freijanes JJ, Crous-Duran J, Paulo JA, Tomé M, Pantera A, Papanastasis VP, Mantzanas K, Pachana P, Papadopoulos A, Plieninger T, Burgess PJ (2017). Current extent and stratification of agroforestry in the European Union. Agriculture, Ecosystems and Environment 241: 121-132. - doi: 10.1016/j.agee.2017.03.005

FAO (2009). Food security and agricultural mitigation in developing countries: options for capturing synergies. Food and Agriculture Organization of the United Nations, FAO, Rome, pp.
82. [online] URL: http://www.fao.org/docrep/ 012/i1318e/i1318eoo.pdf

Foley J (2011). Can we feed the world and sustain the planet? Scientific American 305: 60-65. doi: 10.1038/scientificamerican1111-60

García De Jalón S, Graves A, Moreno G, Palma JHN, Crous-Duran J, Kay S, Burgess PJ (2018). Forage-SAFE: a model for assessing the impact of tree cover on wood pasture profitability. Ecological Modelling 372: 24-32. - doi: 10.1016/j. ecolmodel.2018.01.017

Glover JD, Reganold JP, Cox CM (2012). Agriculture: plant perennials to save Africa's soils. $\mathrm{Na}$ ture 489: 359-361. - doi: 10.1038/489359a

Godfray HCJ, Beddington JR, Crute IR, Haddad L, Lawrence D, Muir JF, Pretty J, Robinson S, Thomas SM, Toulmin C (2012). Food Security: the Challenge of Feeding 9 billion. Science. 327: 812. - doi: $10.4337 / 9780857939388$

Godfray HCJ, Garnett T (2014). Food security and sustainable intensification. Philosophical Transactions of the Royal Society B: Biological Sciences 369: 1-10. - doi: 10.1098/rstb.2012.0273

Gonzalez-Garcia S, Dias AC, Arroja L (2013). Lifecycle assessment of typical Portuguese cork oak woodlands. Science of the Total Environment 452-453: 355-364. - doi: 10.1016/j.scitoten v.2013.02.053

Graves AR, Burgess PJ, Palma JHN, Keesman KJ, Van Der Werf W, Dupraz C, Van Keulen H, Herzog F, Mayus M (2010). Implementation and calibration of the parameter-sparse Yield-SAFE model to predict production and land equivalent ratio in mixed tree and crop systems under two contrasting production situations in Europe. Ecological Modelling 221: 1744-1756. - doi: 10.1016/j.ecolmodel.2010.03.008

Graves AR, Morris J, Deeks LK, Rickson RJ, Kibblewhite MG, Harris JA, Farewell TS, Truckle I (2015). The total costs of soil degradation in England and Wales. Ecological Economics 119: 399-413. - doi: 10.1016/j.ecolecon.2015.07.026 IDAE (2005). Consumos energéticos en las operaciones agrícolas en España [Energetic consumptions in agricultural operations in Spain]. Ministerio de Agricultura, Pesca y Alimentación del Gobierno de España, Madrid, Spain. [online] URL: http://www.idae.es/uploads/documentos/ documentos_10255_Consumos_energeticos_o peraciones_agricolas_Espana_05_d94c1676.pd $f$

IPCC (2006). Guidelines for national gas inventories. Chapter 10 - Emissions from livestock and manure management (Egleston $S$ ed). IGES, Hayama, Japan, pp. 87. [online] URL: http:// www.ipcc-nggip.iges.or.jp/public/2006gl/pdf/4 Volume4/V4_10_Ch10_Livestock.pdf

Jose S (2009). Agroforestry for ecosystem services and environmental benefits: an overview. Agroforestry Systems 76: 1-10. - doi: 10.1007/s10 457-009-9229-7

Kramer KJ, Moll HC, Nonhebel S (1999). Total greenhouse gas emissions related to the Dutch crop production system. Agriculture, Ecosystems and Environment 72: 9-16. - doi: 10.1016/ S0167-8809(98)00158-3

Moreno G, Aviron S, Berg S, Crous-Duran J, Franca A, De Jalón SG, Hartel T, Mirck J, Pantera A, Palma JHN, Paulo JA, Re GA, Sanna F, Thenail C, Varga A, Viaud V, Burgess PJ (2017). Agroforestry systems of high nature and cultural 
value in Europe: provision of commercial goods and other ecosystem services. Agroforestry Systems 92 (4): 877-891. - doi: 10.1007/s10457017-0126-1

Mäkelä K (2002). LIPASTO calculation model: unit emissions of traffic. VTT Technical Research Centre of Finland, Espoo, Finland, Website. [online] URL: http://lipasto.vtt.fi/en/index. htm

Nair PK (2007). The coming of age of agroforestry. Journal of the Science of Food and Agriculture 87: 1613-1619. - doi: 10.1002/jsfa.2897

Palma JHN, Graves AR, Bunce RGH, Burgess PJ, De Filippi R, Keesman KJ, Van Keulen H, Liagre F, Mayus M, Moreno G, Reisner Y, Herzog F (2007). Modeling environmental benefits of silvoarable agroforestry in Europe. Agriculture, Ecosystems and Environment 119: 320-334. doi: 10.1016/j.agee.2006.07.021

Palma JHN, Paulo JA, Tomé M (2014). Carbon sequestration of modern Quercus suber L. silvoarable agroforestry systems in Portugal: a Yield SAFE-based estimation. Agroforestry Systems 88: 791-801. - doi: 10.1007/s10457-014-9725-2

Palma JHN, Graves A, Crous-Duran J, Upson M, Paulo J, Oliveira TS, Garcia De Jalón S, Burgess P (2016). Yield-SAFE model improvements. Report for Milestone 29 (6.4) for the EU FP7 Research Project: AGFORWARD 613520. Lisbon (Portugal) 5 July 2016, pp. 30. [online] URL: http://hdl.handle.net/10400.5/12337

Palma JHN (2017). Clipick - climate change web picker. A tool bridging daily climate needs in process based modelling in forestry and agriculture. Forest Systems 26: 1-4. - doi: 10.5424/fs/ 2017261-10251

Palma JHN, Crous-Duran J, Graves A, Garcia De Jalon S, Upson M, Oliveira T, Paulo J, FerreiroDominguez N, Moreno G, Burgess P (2017a). Integrating belowground carbon dynamics into Yield-SAFE, a parameter sparse agroforestry model. Agroforestry Systems. 92: 1047-. . org. doi: 10.1007/s10457-017-0123-4

Palma JHN, Oliveira TS, Crous-Duran J, Graves A, Garcia De Jalon S, Upson M, Giannitsopoulos $M$, Burgess $P$, Paulo JA, Tomé $M$, FerreiroDominguéz N, Mosquera-Losada MR, Gonzalez-
Hernández P, Kay S, Mirk J, Kanzler M, Smith J, Moreno G, Pantera A, Mantovani D, Rosati A, Luske B, Hermansen J (2017b). Modelled agroforestry outputs at field and farm scale to support biophysical and environmental assessments. Deliverable 6.17 (6.2) of the EU FP7 Research Project: AGFORWARD 613520, pp 162. [online] URL: http://hdl.handle.net/10400.5/147 99

Palma JHN, Cardoso RM, Soares PMM, Oliveira TS, Tomé M (2018). Agricultural and forest meteorology using high-resolution simulated climate projections in forest process-based modelling. Agricultural and Forest Meteorology 263: 100-106. - doi: 10.1016/j.agrformet.2018.08. 008

Pereira PM, Fonseca MP (2003). Nature vs. nurture: the making of the montado ecosystem. Conservation Ecology 7(3): 7. [online] URL: http://www.consecol.org/vol7/iss3/art7/

Petersen B, Snapp S (2015). What is sustainable intensification? Views from experts. Land Use Policy 46: 1-10. - doi: 10.1016/j.landusepol.2015. 02.002

Pinto-Correia T (1993). Threatened landscape in Alentejo, Portugal: the "montado" and other agro-silvo-pastoral systems. Landscape Urban Planning 24: 43-48. - doi: 10.1016/0169-2046(93) 90081-N

Pinto-Correia T, Ribeiro N, Sá-Sousa P (2011). Introducing the montado, the cork and holm oak agroforestry system of Southern Portugal. Agroforestry Systems 82: 99-104. - doi: 10.1007/ s10457-011-9388-1

Rajaniemi M, Mikkola H, Ahokas J (2011). Greenhouse gas emissions from oats, barley, wheat and rye production. Agronomy Research 9: 189195. [online] URL: http://www.researchgate. net/publication/264892275

Rivest D, Rolo VV, López-Díaz L, Moreno G, Lopez-Diaz L, Moreno G (2011). Shrub encroachment in Mediterranean silvopastoral systems: Retama sphaerocarpa and Cistus ladanifer induce contrasting effects on pasture and Quercus ilex production. Agriculture, Ecosystems and Environment 141: 447-454. - doi: 10.1016/j. agee.2011.04.018
Rosado MM (2009). Contributo para a integração da componente ambiental na avaliação económica de sistemas de produção agropecuários [Contribute for the integration of the environmental component in the economic evaluation of farming systems production]. PhD Dissertation, Evora University, Portugal, pp. 335. [in Portuguese] [online] URL: http:// hdl.handle.net/10174/4269

Sereke F, Graves AR, Dux D, Palma JHN, Herzog $F$ (2015). Innovative agroecosystem goods and services: key profitability drivers in Swiss agroforestry. Agronomy for Sustainable Development 35: 759-770. - doi: 10.1007/s13593-014-026 1-2

Siddique KHMM, Belford RK, Tennant D (1990). Root:shoot ratios of old and modern, tall and semi-dwarf wheats in a Mediterranean environment. Plant and Soil 121: 89-98. - doi: 10.1007/BF 00013101

Tilman D, Balzer C, Hill J, Befort BL (2011). Global food demand and the sustainable intensification of agriculture. Proceedings of the National Academy of Sciences USA 108: 20260-20264. doi: $10.1073 /$ pnas.1116437108

Torralba M, Fagerholm N, Burgess PJ, Moreno G, Plieninger T (2016). Do European agroforestry systems enhance biodiversity and ecosystem services? A meta-analysis. Agriculture, Ecosystems and Environment 230: 150-161. - doi: 10.1016/j.agee.2016.06.002

Van Der Werf W, Keesman K, Burgess PJ, Graves AR, Pilbeam D, Incoll LD, Metselaar K, Mayus M, Stappers R, Van Keulen H, Palma JHN, Dupraz C (2007). Yield-SAFE: a parameter-sparse, process-based dynamic model for predicting resource capture, growth, and production in agroforestry systems. Ecological Engineering 29 (4): 419-433. - doi: 10.1016/j.ecoleng.2006.09. 017

Vermeulen SJ, Campbell BM, Ingram JS (2012). Climate change and food systems. Annual Review of Environment and Resources 37: 195222. - doi: 10.1146/annurev-environ-020411-1306 08 